\title{
THE ROLE OF CONSIDERATION OF THE VALUE OF RISKS, SHAME AND GUILT IN UTILITARIAN MORAL JUDGMENT ON ACADEMIC DISHONESTY BEHAVIOR
}

\author{
Imaduddin Hamzah ${ }^{1 *}$, Iman Santoso ${ }^{1}$, Nazhifah Imaduddin ${ }^{2}$ \\ ${ }^{1}$ Politeknik Ilmu Pemasyarakatan, Indonesia \\ ${ }^{2}$ Universitas Negeri Makassar, Indonesia \\ *e-mail: imaduddin@poltekip.ac.id
}

\begin{abstract}
Students generally know that cheating and plagiarism are violations of academic ethics, but some still do it. The study of academic dishonesty has been more into quantitative approaches, thus it cannot explain the dynamics of moral psychology about the decision making of cheating and plagiarism. This study explores the role of the consideration of the value of risk, shame, and guilt in utilitarian moral judgment in academic dishonesty behavior, as a solution to the views of theoretical debates about the role of emotions and cognitive morals in explaining good and bad behavior. This research used an interpretative phenomenological analysis approach to explore the meaning of the experience of conducting academic dishonesty by interviewing 66 college students. The results showed that ignorance of shame and the absence of guilt played a role in weakening the utilitarian moral judgment of students to act honestly in the face of examinations and assignments. These findings contributed to the importance of strengthening moral and ethical education for students in academic programs.
\end{abstract}

Keywords: consideration of the value of risks, shame, guilt, utilitarian moral judgment, academic dishonesty

\section{PERAN PERTIMBANGAN NILAI RISIKO, RASA MALU DAN RASA BERSALAH DALAM UTILITARIAN MORAL JUDGMENT PADA PERILAKU KETIDAKJUJURAN AKADEMIK}

\begin{abstract}
Abstrak: Mahasiswa umumnya mengetahui bahwa mencontek dan plagiarisme adalah pelanggaran etika akademik, tetapi sebagian mahasiswa tetap melakukannya. Studi tentang ketidakjujuran akademis lebih banyak menggunakan pendekatan kuantitatif, belum dapat menjelaskan dinamika psikologi moral tentang pengambilan keputusan menyontek dan melakukan plagiarisme. Studi ini mengeksplorasi tentang peran pertimbangan nilai resiko, rasa malu dan bersalah dalam utilitarian moral judgment pada perilaku ketidakjujuran akademik, sebagai solusi pandangan terhadap perdebatan teoretis tentang peran emosi dan moral kognitif dalam menjelaskan perilaku baik dan buruk. Penelitian ini menggunakan pendekatan interpretative phenomenological analysis untuk mengeksplorasi makna pengalaman melakukan ketidakjujuran akademik dengan mewawancarai enam puluh enam mahasiswa. Hasil penelitian menemukan bahwa pertimbangan nilai risiko, pengabaian rasa malu dan ketidakhadiran rasa bersalah berperan melemahkan utilitarian moral judgment mahasiswa untuk bertindak jujur dalam menghadapi ujian dan tugas kuliah. Temuan penelitian ini berkontribusi pada pentingnya penguatan pendidikan moral dan etika bagi siswa dalam program akademik.
\end{abstract}

Kata Kunci: pertimbangan nilai resiko, rasa malu, rasa bersalah, utilitarian moral judgment, ketidakjujuran akademik

\section{INTRODUCTION}

The theoretical debate about moral violations between the point of view of moral cognition and moral emotion has been going on for a long time. The hypothesis about moral valuation theory is currently seen as difficult because the views of rational and emotional decision processes compete with each other
(Cohen \& Ahn, 2016). Some moral cognition experts strongly believe that moral reasoning, moral judgment, and moral thinking determine the actions of individuals, whether good or bad. As proposed by Greene \& Haidt (2002), based on his studies, he found a significant role of reasoning in moral judgment. However, this view of the cognitive field gained opposition 
from an moral emotion researcher who argued whether or not the individual action was a result of emotional response, such as shame, guilt, embarrassment. This view was reinforced by several studies suggesting that moral emotions affect prosocial behavior (Torstveit, Sütterlin, \& Lugo, 2016), behavioral offenses (Day, 2014), and social commitments (Keltner, Horberg, \& Oveis, 2006).

Other experts try to mediate the debate of moral cognition and emotions, with the opinion that there is the involvement of reasoning and emotional awareness towards moral decision making. According to Haidt (2001), moral judgment evaluates good-bad actions by reasoning processes (cognition), also involves affective valence (good-bad, likes-dislikes) that occurs automatically and unconsciously (Waldmann, Nagel, \& Wiegmann, 2012). This research explored the role of moral emotion involvement in moral decision making in academic dishonesty behavior.

Academic dishonesty is a form of moral violation in the world of higher education. "Academic dishonesty is an act which includes" cheating, 'cheating,' and" plagiarism, "theft of ideas and other forms of intellectual work" (Jones, 2001: 2). According to Jones (2001), cheating is any attempt to cheat or cheat by ignoring values and norms to obtain unfair advantages. Plagiarism is the activity of taking other people's ideas and then recognizing them as their work, or paraphrasing the writing in their sentences, taking the whole text and then rewriting it (Zalnur, 2012).

Some recent studies on academic dishonesty with a quantitative approach are still very dominant. A bibliography study with the academic dishonesty theme of 1332 publications (early 1960-2017) stated that many studies identified correlation and influence of factors on the behavior of academic dishonesty (Marques, Reis, \& Gomes, 2019). Similarly, some of the studies in some countries are usually conducted a statistical analysis of factors correlated and predictors. The meta-analysis of seventeen international publications found that conscientiousness and agreeableness are the strongest predictor of academic dishonesty (Giluk \& Postlethwaite, 2015). The findings of the survey against students in Russia who conducted academic dishonesty found that the subjective norm dominates as the most reliable predictor and its weak control of behavior is positively linked to dishonest behavior (Maloshonok \& Shmeleva, 2019).

Meanwhile, some studies were conducted in the Middle East, and China used quantitative methods. Research Ahmed, (2018) found that $65 \%$ of private students do cheating using mobile phones and tablets. Studies using regression analysis reveal that gender, perception of peers, and seriousness awareness of the academic dishonesty of Chinese and Taiwanese students into significant variables predicting themselves of self-reported academic dishonesty (Yang, Chiang, \& Huang, 2017), demographic variables, academic orientation, and self-efficacy have a predictor value on the behavior of cheating, plagiarism, and falsification of students in Australia (Marsden, Carroll, \& Neill, 2005).

The study of the methods used in many plagiarism articles and cheating found that most articles used a quantitative approach (e.g. Warsiyah, 2015; Santoso \& Yanti, 2016; Silvana, Rullyana, \& Hadiapurwa, 2017). These articles did not count the subjective dynamics of why students commit academic dishonesty. The findings of the study put forward more psychological determinants or factors that correlate with academic dishonesty, such as attitudes and levels of education (Cahyo \& Solicha, 2014), fear of academic failure (Fatimah, 2018), self-confidence (Reyaan \& Hary, 2017), and cheating self-efficacy (Hendiarto \& Hamidah, 2014).

Student academic dishonesty, such as cheating behavior and plagiarism is an act that has a personal psychological background. This study aims to explore the role of shame and guilt in the moral decisions of individuals committing academic, moral violations (cheating and plagiarism). Understanding the morality of decision-making and individual emotions towards cheating and plagiarism will be described through the interpretation of the individual's experience. Theoretically, this study provides a more in-depth explanation of the moral relations of cognition and emotional morals that there are currently many psychologists who debate it.

The prohibition of cheating and plagiarism are moral values that are instilled by educational institutions to students since elementary school. Parents and teachers have internalized that 
cheating is bad behavior. Someone who cheats and plagiarism will get formal sanctions and punishment (assessment does not pass) and social (shame).

Shame and guilt, including pride, are members of the "self-conscious emotion" group that is generated by self-reflection and self-evaluation (Tangney, Stuewig, \& Mashek, 2007). Shame is a form of emotional awareness. Shame is a form of individual self-evaluation of his actions based on standards, rules, and norms (Lewis, 2011). According to Tangney (1990), Individuals with shame experiences experience significant changes in self-perception, accompanied by feelings of self-disclosure, feelings of worthlessness, and helplessness. Guilt is an uncomfortable moral emotion that occurs when someone has violated social norms (Torstveit et al., 2016). According to Grainger (2004), the emotions of guilt are negative feelings that people can experience because of mistakes, such as dishonesty or deceiving others.

Moral psychology studies have long focused on aspects of reasoning. In the view of utility (consequentialism), moral decisions are controlled by "cognitive" processes. In cognitive processes, utilitarian reasoning constructs hypotheses to be logical and controlled. It determines the weight in determining utility goals, which will lead to conclusions on useful goals (Cohen \& Ahn, 2016) so that moral decision making always aims to produce all the best consequences for all parties, directly or indirectly (Greene, 2007). However, some recent evidence shows that moral judgment is more a matter of emotional and affective intuition than deliberate reasoning (Greene \& Haidt, 2002). According to Paxton \& Greene (2010), in utilitarian moral judgments, judgments are naturally considered to reflect concerns about rights and obligations, driven primarily by intuitive emotional responses. The dualprocess theory that embraces the cognitive and moral perspectives of emotions suggests that cognitive processes and automatic emotional responses control utilitarian moral judgments. However, some data have not shown a causal relationship between emotional responses and moral decisions (Greene, Morelli, Lowenberg, Nystrom, \& Cohen, 2008).

This study proposes a theoretical and empirical debate solution between cognitive and emotional perspectives in explaining moral acts of violation. The involvement and integration of moral cognition and moral emotion in decision making can be in the context of the process and dynamics of interaction between these factors. This study aims to explore the role of consideration of the value of risk, shame, and guilt in the process of utilitarian moral judgment in academic dishonesty behavior. An essential benefit of the explanation of the results of this study is the need to strengthen moral education and academic ethics programs for students with different backgrounds of moral standards.

\section{METHODS}

The current research used the interpretative phenomenological analysis (IPA) method. This qualitative approach aims to understand and present one's experience and actions as they experience, engage, and live in a situation (Elliott, Fischer, \& Rennie, 1999). The IPA method is used to explore in detail how the informant understands their personal and social worlds, and the main focus is the meaning of experience, events, certain circumstances for participants (Smith \& Osborn, 2008). With this approach, the experiential of reasoning and emotional process experience of the participants ' moral decisions are excavated in the context of academic dishonesty actions. IPA can examine the details of individual life experiences and how individuals understand their experiences (Eatough \& Smith, 2008).

\section{Participants}

The IPA offers adaptations and approaches intended to provide a personal privilege to provide complete and in-depth explanations (Pringle, Drummond, McLafferty, \& Hendry, 2011). Phenomenological analysis focuses on personal meaning, and its relationship with the world at an individual level (Larkin, Shaw, \& Flowers, 2019). The choice of subjects in the IPA's operationalization is based on the effort to understand the specific phenomenon from the perspective of a particular group (Smith \& Osborn, 2008). Research focuses on the issue of cheating and plagiarism conducted by college students when working on exams, making papers, and thesis. Research has been conducted at a private college in Tangerang City, Banten Province, Indonesia. Participants have been 
recruited through a self-reported survey of ever/ yet cheating or plagiarism to students originating from six departments. Of the 120 students who populate the survey, purposive sampling reported seventy-nine students who claimed to have been cheating or plagiarism. Sixty-six student participants who have expressed a willingness to interview about their experience.

Student participants who were selected and willing to take part in the interview consisted of 54.5 percent of men $(n=36)$ and 45.5 percent of women $(n=30)$. The age range of informants was mostly at the age of $18-19$ years $(n=40)$ of 60.6 percent. Ages $20-21$ years $(n=19)$ and 2224 years $(n=7)$, respectively 28.8 percent and 10.6 percent.

\section{Procedures}

The technique of data collection with the IPA method, gives participants the possibility to give detailed explanation in their own words. IPA interprets individual experiences, obtained through various means. Including interviews, conversations, observations, personal experiences, and textual analysis (Kidd, 2002). IPA researchers analyze in detail how participants feel and understand things that happen to them (Smith \& Osborn, 2008). Researcher explain to participants that all statements from interviews are transcribed under an anonymous name to ensure their confidentiality and privacy.

The data collection of this study used a semi-structured interview technique using Indonesian. Semi-structured interviews have the character of interactive dialogue exchange, a relatively informal style, centered on topic themes, and researchers ask questions flexibly and without being sequenced, allowing researchers to develop unexpected themes (Jason, 2002). Participants who have stated their willingness to be contacted by telephone to determine the schedule of interviews. Participant interviews were conducted for 20-30 minutes recorded using a voice recorder. Interview questions include the reasons for cheating and plagiarism, the benefits, and the views of informants about cheating and plagiarism as behavior that violates academic norms and ethics. Furthermore, the recording of interview results is transcribed, classified, and coded manually according to the concepts and themes that emerge.
To find themes in the form of meaning units, researchers conducted an interview transcript analysis. Collins and Nicolson (2002), as quoted by Brocki \& Wearden (2006), use this stage of analysis to make any notes in the contents of transcripts, relating the previous literature and the design of theoretical models of research topics. The next stage of analysis looks for connections between themes with a logical approach and grouping themes. The informant's answers describe the meaning of the individual to his experience of cheating and plagiarism, breaking it down into specific sub-themes and themes.

\section{RESULTS AND DISCUSSION Results}

Explanation of each participant from the interview results illustrates the understanding, experience and activities carried out in the context of cheating behavior and their plagiarism, including self-assessment of the actions they take. Researchers try to capture participants' experiences of dishonesty, and identify the core structure and characteristics of their experiences. In this process the researcher tries to break free from prejudice, and carefully describe the meaning of participants' understanding and experience based on the story being told. The results of the study using science to the experience of students cheating and plagiarism have gained three main themes as shown in Table 1. To maintain confidentiality and ethical reasons, citation transcripts of participant interviews on the results of this study use a pseudonym.

\section{Theme I: Consideration of the value of risk}

The results of the participant interviews showed that cheating and plagiarism were actions taken based on the consideration of reducing the estimated risk of loss. Estimated losses will be received by calculating if it fails to complete the exam and make a good paper. Consideration of the value of risk is the process of comparing and assessing an action and the possible consequences obtained if the actions of cheating and plagiarism are done or not done. This theme includes sub-themes consisting of consequences, self-efficacy, ease and efficiency of time, and situation appraisal. The sub-theme is arranged based on the concept identification code, from the participant's answer, as follow: 
Tabel 1. Themes and Subthemes Academic Dishonesty

\begin{tabular}{|c|c|c|c|}
\hline No. & Main Themes & Subthemes & Keywords \\
\hline \multirow[t]{5}{*}{1.} & $\begin{array}{l}\text { Consideration of } \\
\text { the value of risks }\end{array}$ & Consequences & $\begin{array}{l}\text { High grades, don't want bad grades, don't get } \\
\text { sanctions }\end{array}$ \\
\hline & & Self efficacy & $\begin{array}{l}\text { Lack of understanding, do not know how to do, } \\
\text { lack of preparation, brain stuck, confused, lack of } \\
\text { confidence in the answers themselves }\end{array}$ \\
\hline & & $\begin{array}{l}\text { Ease and efficiency } \\
\text { of time }\end{array}$ & Doing fast, easy, not complicated, saves time \\
\hline & & Time pressure & Short time, divide the other busy time, pressing \\
\hline & & Situation appraisal & $\begin{array}{l}\text { Careless supervisors, many college assignments, } \\
\text { urgent conditions }\end{array}$ \\
\hline \multirow[t]{2}{*}{2.} & $\begin{array}{l}\text { Ignorance of the } \\
\text { shame }\end{array}$ & Apathetic & $\begin{array}{l}\text { It's each other's business, just leave it be, I don't } \\
\text { care, just ignore it }\end{array}$ \\
\hline & & $\begin{array}{l}\text { Social } \\
\text { reinforcement }\end{array}$ & $\begin{array}{l}\text { Other people also do it, cooperate with each other, } \\
\text { Other students have also, has become a culture, } \\
\text { common today }\end{array}$ \\
\hline \multirow[t]{3}{*}{3.} & Absence of guilt & Realistic choice & $\begin{array}{l}\text { Forced, what can I do, the instant way of good } \\
\text { grades }\end{array}$ \\
\hline & & Justification & $\begin{array}{l}\text { Trapped time, sophisticated times the number of } \\
\text { works shared, demands good grades, not copying } \\
\text { all, for additional material, helping complete } \\
\text { deadline assignments }\end{array}$ \\
\hline & & Social beliefs & $\begin{array}{l}\text { It's normal, people are used to it, it's a common } \\
\text { thing, friends also cheat }\end{array}$ \\
\hline
\end{tabular}

I cheated for fear of my bad grades and afraid of remedial, do not want to bother, and do not want to think long, copy and paste from Google, change the writing a little. (Latif)

My main goal is to get the assignment done quickly and get good grades. (Erry)

The participants' answers about Theme 1 show that there was a weak state of participant's self-confidence to complete working on exams and assignments (self-efficacy). This reasoning is revealed from the meaning of the participant's answer keywords as listed in Table 1 contains the lack of understanding, do not know how to do, lack of preparation, brain stuck, confused, lack of confidence in the answers themselves. These words present a picture of the experience that participants assess the readiness and capability itself, unable to deal with the situation exams and assignments. The informant also showed a low effort to face the situation of demanding good grades, mastering material and writing papers, expressed in words, "lazy, no enthusiasm. "

Time limit pressure becomes a significant situational factor that suppresses participants from cheating and plagiarism. Participants interpret cheating and plagiarism as a response to limited time and take advantage of opportunities.
The following excerpt statement related to the meaning of the sub-theme: time pressure, situation appraisal:

At that time the supervisor was off guard. (Najwa)

My main goal is to get the assignment done quickly and get good grades. (Mustofa)

Theme findings "consideration of the value of benefits" illustrates moral acts of violation (cheating and plagiarism) using an assessment of the calculation of the magnitude of benefits and immediate benefits. Informants expect to get a result of their actions in the form of high-value results (avoid low value), faster completion time, time limit pressure solutions, low mobilization of business energy, with low self-efficacy roles. When comparing with honesty, informants interpret their actions as having more significant benefits. Not cheating or obeying the rules of writing scientific papers is not the right decision because it has a risk of adverse effects as a student.

I want to get good grades and save time because I don't need to think hard, just copy. (Agil) 


\section{Theme 2: Ignorance of shame}

Shame is related to public disclosure of individual shortcomings or mistakes. Shyness represents participants' emotional awareness of the possibility of other people's reactions to acts of violating social norms. Ignorance of shame arises when informants deny other people's responses to wrongdoing (cheating and plagiarism), with apathetic and social reinforcement. Statement of participants with academic dishonesty with the words "normal" and do not feel cheating. The meaning of the participant's experience that social responses are not wrong reinforces the lack of shame over his dishonest actions.

My view is normal to them. Instead, they joined in cheating. Do I cheat, he also did it. (Aswan)

They also cheat, I enjoy. (Indra)

Some of the participant's statements have the meaning that the act of academic violation is not an embarrassment. The participants felt that the violation was a personal action, but could be socially tolerated so that there was no adverse social risk. The disregard for shame in the practice of academic dishonesty, showing low emotional awareness, weakens the decision of students to do academic honesty.

\section{Theme 3: Absence of guilt}

Guilt appears as an evaluation of personal and confidential emotional awareness, after taking an action that is immoral and by social norms. Participants know and realize cheating and plagiarism are violations of ethics and morals in the academic environment. Feelings of guilt also involve negative assessments of student behavior, the emergence of feelings of tension, and sincere regret.

The participant's answer with sub-themes realistic choices, justifications, and social beliefs, precisely illustrates that the informant believes that he has made a personal decision that is right and gets excellent benefits. The participants interpreted consciously cheating, and plagiarism was not an act of violating social normality for himself, so it did not show remorse for his actions. One informant stated:

Cheating is okay. Cheating is not always negative, plagiarism too. According to me personally, that has a positive side. This cheating among people is a familiar, common or prevalent. (Aswan)

Guilt is related to self-regret for actions that violate personal moral standards. However, the participant's answer when asked about cheating behavior and plagiarism that has been done reflects the regrets of moral standards. Regret arises when participants do not get value or benefit from cheating and plagiarism. This response is more describing disappointed emotions, such as the answer of an participant who stated:

Take it easy, because the exam questions are difficult to answer, and if the grades are good, very grateful. But if the value is low, I become upset. (Kodri)

\section{Discussion}

Studies have found that cheating and plagiarism informant considers better gains in the process of choosing action - analysis of profit actions along with the calculation of losses to be gained. The conclusions taken are determined by the power of the causal relationship between action and outcome (Elqayam, Wilkinson, Thompson, Over, \& Evans, 2017). Greene et al. (2008) argue that the assessment of the consequences/utilitarian for a greater good is support controlled cognitive process that looks like moral reasoning (Paxton \& Greene, 2010). The perception of loss in moral judgment is based on two possible reasons, the first perception of danger that reflects the moral of thinking to justify itself, the second is the danger fundamental to the fundamental foundation undertaken and defended by moral judgment (Schein \& Gray, 2018).

The philosophy of consequentialism states that the truth or error of action is based on the 'goodness' or 'badness' of the consequences of the action (Robertson \& Walter, 2007). But according to this view, right or justified actions depend on the consequences of cause and effect; they have more intrinsic value than alternative actions (Brink, 1986). This value is related to welfare or happiness.

Individuals understand that academic dishonesty is not a good action. Based on the results of the interview, morally, they already have the view that cheating and plagiarism are acts that violate academic standards and 
norms. But the confusion in decision making and action occurs when individuals consider the consequences of honest or dishonest actions. The internalized moral basis of individuals states that academic dishonesty is bad deeds. Personal values can change when individuals face a dilemma between the advantages and disadvantages of their actions. Individuals redefine good and bad deeds in exam situations and complete urgent paper assignments.

The results of this study found that consideration of cognitive usefulness became a strong foundation of academic dishonesty. According to Prihantini \& Indudewi (2016), based on the concept of rewards and punishment, student plagiarism is one of the actions that consequently gets good grades as prizes and avoids lecturers' anger as punishment. Mujahidah (2018) links this benefit with the achievement of goals with cheating behavior, which is to improve grades, not fail tests, and the need for recognition..

The cognitive process of the informant produces a view of 'low value' as an unpleasant condition (punishment), causing fear of failure (Fatimah, 2018). While 'good value' as a goal that provides pleasant benefits (reward). Decision-makers must assess and compare the consequences of each action, then draw normative conclusions made specifically (Elqayam et al., 2017).

Academic dishonesty, based on a utilitarian moral judgment explanation, related to achieving well-being or safety, results in pleasure or satisfaction preferences for subjective desires (Brink, 1986). Moral assessment is based on principles driven by controlled cognitive processes, considering the consequences of actions, ie, good things are what produce the best results for most people (Elqayam et al., 2017; Greene, 2007). The choice of utilities that most determine the maximum decision making the decision to take action, after comparing it with the risks and uncertainties that will occur (Sheng, 1998).

The reasoning for the benefits (utility) of dishonesty in this study found an effect of self-efficacy. Individuals who show a lack of confidence in their abilities get high marks. This personal situation reinforces the value of the benefits and justification for his dishonesty. This finding is in line with the conclusions of the study of Shara (2016) and Aulia (2015), which revealed that someone who has high selfefficacy, will have low cheating behavior.

Self-conscious emotions play a central role in motivating and managing most of the thoughts, feelings, and behavior of individuals (Tracy \& Robins, 2007). Hume states that moral judgment is a result of previously different emotions (Waldmann et al., 2012). Emotions such as shame and guilt are moral emotions that are key elements of the moral set of human beings, which affect the relationship between moral standards and moral behavior (Tangney et al., 2007). The results of this study indicate that moral, emotional conditions such as low shame and absence of guilt reinforce academic dishonesty decisions. Students reconsider the act of violating academic norms to be able to accept it. This tolerance is present because of a shift in the meaning of the right actions in a situational manner.

Shame qualifies as a dominant moral emotion, as one moves beyond the narrow conception of morality in terms of an autonomous ethic (Shweder, Much, Mahapatra, \& Park, 1997). Individuals who cheat and plagiarism ignore the shame that arises in themselves because they consider it the most realistic choice, justification, and the belief that the action has no impact on social sanctions. So shyness illustrates a complex set of cognitive activities: evaluation of individual actions concerning their standards, rules, and goals, and global evaluation of themselves (Lewis, 2011). Shame also qualifies as a dominant moral emotion, as one moves beyond the narrow conception of morality in terms of autonomy ethics (Shweder et al., 1997).

Kedia \& Hilton have found that regretting actions can cause painful "hot" emotions, whereas regret in actions is more likely to cause feelings of sadness (Gilovich, Medvec, \& Kahneman, 1998). The psychological strength of emotions, such as guilt, enables individuals to obey the norms and values of academic honesty. According to Tracy \& Robins (2004), individuals who try hard to be "good people" or treat others well, if doing such actions create pride in ourselves. However, if someone fails to do it, emotional awareness will appear like guilt or shame towards oneself. Moral emotions are adaptive to social functions and cohesion, motivating individuals to correct wrong behavior 
or keep themselves following the norms of behavior (Torstveit et al., 2016).

The results of this study are in line with studies conducted by Torstveit et al. (2016). They concluded based on several studies that some individuals are more likely to think, feel, and act more ethically because of the lower threshold for experiencing guilt. Guilt combined with empathy can explain differences in prosocial behavior (Torstveit et al., 2016). If the student's position suffers from pressure, they tend to ignore the guilt, because they do not want to get punished (Prihantini \& Indudewi, 2016).

According to Day (2014), metaphorically describing guilt as a bulky or heavy burden on one's conscience (Day, 2014). Feelings of guilt can arise following an individual action or non-action contrary to personal or community standards (lying, cheating, and stealing). Guilt as self-awareness and moral emotion because it involves self-evaluation, and plays an essential role in guiding moral behavior. Apart from feeling bad, feelings of regret, and tension colored guilt. Emotions of guilt or regret are present when individuals evaluate their behavior as a failure but focus on specific features of the self, or on self-action that lead to failure (Lewis, 2011).

According to Bogolyubova \& Kiseleva (2016), situational experiences of shame are part of one's healthy psychological life and have adaptive functions. Shyness contributes to the normalization of social interaction and the maintenance of group norms because shyness is an indicator of individuals experiencing social threats, threats of rejection and exclusion from groups (Bogolyubova \& Kiseleva, 2016).

Narcissistic tendencies on the informant and plagiarism are seen with the absence of guilt and ignoring the shame. According to Poless, Torstveit, Lugo, Andreassen, \& Sütterlin (2018), Narcissists are described as individuals with dysfunctional personality traits such as lack of psychological awareness and empathy. Guilt absence is described from a negative evaluation of the unethical conduct of the informant, and whether this evaluation can affect the tendency of unethical action. Shame is also a negative evaluation of oneself, which then affects decision-making tendencies to conduct or conceal unethical academic behaviors.
Participants see the possibility of reducing the risk of low grades with academic dishonesty, thereby ignoring shame and guilt in making moral decisions. This conclusion encourages universities to make efforts to improve students' moral honesty. The study Roberts, Thomas, Novicevic, Ammeter, Garner, Johnson, \& Popoola (2018) found that moral beliefs predict students' moral disengagement and subsequent unethical decision making related to academic dishonesty not only directly but also indirectly through the philosophy of ethics and moral identity of students. By being honest, learning outcomes can be better. The findings of the experimental study stated that there was a significant difference between the learning outcomes of the experimental class and the control class in which the honesty of the experimental class students was in the very good category and the control class was in a good category (Sitorus \& Kristiani, 2019). The right strategy is to internalize moral values in the learning process by modeling, analyzing actual problems in the community, developing contextual education of values, and strengthening moral values that students have (Murdiono, 2010).

\section{CONCLUSION}

Academic dishonesty is an act that results from utilitarian moral judgment based on the value of benefits. Several reasons underlie the assessment of benefits, including the calculation of the consequences of business results, assessment of self-efficacy, self-efficacy, time pressure, and situation assessment. Consideration of the value of these benefits alienates individuals from moral standards when moral emotions, such as shame and guilt, weaken. This study also proposes a slightly different view from Haidt (2001), who argues that cognitive and affective processes in moral judgment occur not automatically and consciously. This study found that the process of individual moral decisions can be done not automatically but through a conscious process of ignoring moral emotions that reinforce moral infringement decisions. Based on the findings of this research the organizers of higher education and educators need to pay attention about the internalization program values of honesty and academic ethics of students since the beginning. 


\section{REFERENCES}

Ahmed, K. (2018). Student perceptions of academic dishonesty in a Private Middle Eastern University. Higher Learning Research Communications, 8(1), 16-29. doi:10.18870/hlrc.v8i1.400.

Aulia, F. (2015). Factors related to academic cheating on students. Jurnal RAP UNP, 6(1), 23-32. doi:10.24036/rapun. v6i1.6647.

Bogolyubova, O. N. \& Kiseleva, E. V. (2016). Experiencing shame. Russian Education \& Society, 58(11), 675-695. doi:10.1080 $/ 10609393.2016 .1342191$.

Brink, D. O. (1986). Utilitarian morality and the personal point of view. Journal of Philosophy, 83(8), 417-438. doi:10.2307/2026328.

Brocki, J. M. \& Wearden, A. J. (2006). A critical evaluation of the use of interpretative phenomenological analysis (IPA) in health psychology. Psychology and Health, 21(1), 87-108. doi:10.1080/14768320500230185.

Cahyo, S. D. \& Solicha. (2014). Factors that influence cheating behavior on students and students in Jakarta. JP3I, VI(1), 133141. doi:10.13140/ RG.2.2.30630.32324.

Cohen, D. J. \& Ahn, M. (2016). A subjective utilitarian theory of moral judgment. Journal of Experimental Psychology: General, 145(10), 1359-1381. doi:10.1037/xge0000210.

Day, M. V. (2014). Guilt. In T. R. Levine (Ed.), Encyclopedia of deception. Thousand Oaks, CA: SAGE Publications, pp. 427429. doi:10.4135/9781483306902.n16.

Eatough, V., \& Smith, J. A. (2008). Interpretative phenomenological analysis. In C. Wilig \& W. Stainton-Rogers (Eds.). The sage handbook of qualitative research in psychology. Los Angeles: SAGE Publications, pp. 193-211.

Elliott, R., Fischer, C. T., \& Rennie, D. L. (1999). Evolving guidelines for publication of qualitative research studies in psychology and related fields. British Journal of Clinical Psychology, 38(3), 215-229. doi:10.1348/014466599162782.

Elqayam, S., Wilkinson, M. R., Thompson, V. A., Over, D. E., \& Evans, J. S. B. T. (2017). Utilitarian moral judgment exclusively coheres with inference from is to ought. Frontiers in Psychology, 8(JUN), 1-18. doi:10.3389/fpsyg.2017.01042.

Fatimah, D. G. (2018). Fear of failure and the intention of plagiarism in students. Jurnal Psikologi Ulayat, 5(1), 46-59. doi:10.24854/jpu12018-177.

Giluk, T. L., \& Postlethwaite, B. E. (2015). Big Five personality and academic dishonesty: A meta-analytic review. Personality and Individual Differences, 72(2015), 59-67. doi:10.1016/j.paid.2014.08.027.

Grainger, R. (2004). Forgiveness and liturgy. In F. N. Watts \& L. Gulliford (Eds.). Forgiveness in context: Theology and psychology in creative dialogue. London: T \& T Clark, pp. 69-82.

Greene, J. D. (2007). The secret joke of Kant's soul. In W. Sinnott-Armstrong (Ed.). Moral Psychology: The neuroscience of morality: emotion, disease, and development. Cambridge, MA: MIT Press, pp. 35-80.

Greene, J. \& Haidt, J. (2002). How (and where) does moral judgment work? TRENDS in Cognitive Sciences, 6(12), 517-523. doi:10.1016/S1364-6613(02)02011-9.

Greene, J. D., Morelli, S. A., Lowenberg, K., Nystrom, L. E., \& Cohen, J. D. (2008). Cognitive load selectively interferes with utilitarian moral judgment. Cognition, 107(3), 1144-1154. doi:10.1016/j. cognition.2007.11.004.

Hendiarto, Y. \& Hamidah, H. (2014). Hubungan antara self efficacy dengan perilaku menyontek saat ujian pada mahasiswa Universitas Esa Unggul. [The relationship between self-efficacy and cheating behavior during exams at Esa Unggul 
University students]. Journal Psikologi Klinis dan Kesehatan Mental, 3(2), 85-89. https://digilib.esaunggul.ac.id/hubunganantara-self-efficacy-dengan-perilakumenyontek-saat-ujian-pada-mahasiswauniversitas-esa-unggul-6134.html.

Jason, J. (2002). Qualitative researching (Vol. 2). London: SAGE Publications.

Jones, L. R. (2001). Academic integrity \& academic dishonesty: A handbook about cheating \& plagiarism. https://repository. lib.fit.edu/handle/11141/2601.

Kedia, G. \& Hilton, D. J. (2011). Hot as hell! The self-conscious nature of action regrets. Journal of Experimental Social Psychology, 47(2), 490-493. doi:10.1016/j.jesp.2010.10.017.

Keltner, D., Horberg, E. J. \& Oveis, C. (2006). Emotions as moral intuitions. In J.P. Forgas (Ed.). Affect in social thinking and behavior. New York, NY: Psychology Press, pp. 161-175.

Kidd, S. A. (2002). The role of qualitative research in psychological journals. Psychological Methods, 7(1), 126-138. doi:10.1037/1082-989X.7.1.126.

Larkin, M., Shaw, R., \& Flowers, P. (2019). Multiperspectival designs and processes in interpretative phenomenological analysis research. Qualitative Research in Psychology, 16(2), 182-198. doi:10.1080/ 14780887.2018.1540655.

Lewis, M. (2011). The self-conscious emotions. In L. R. Williams, \& D. P. Fromberg (Eds.). Encyclopedia on early childhood development. New York, NY: Routledge, pp. 1-5.

Maloshonok, N. \& Shmeleva, E. (2019). Factors influencing academic dishonesty among undergraduate students at Russian Universities. Journal of Academic Ethics, 17(3), 313-329. doi:10.1007/s10805-0199324-y.

Marsden, H., Carroll, M., \& Neill, J. T. (2005). Who cheats at university? A self-report study of dishonest academic behaviours in a sample of Australian university students. Australian Journal of Psychology, 57(1), 1-10. doi:10.1080/000495304123312834 26.

Marques, T., Reis, N., \& Gomes, J. (2019). A Bibliometric study on academic dishonesty research. Journal of Academic Ethics, 17(2), 169-191. doi:10.1007/ s10805-019-09328-2.

Mujahidah, M. (2018). Situational factors, objective orientation, and locus of control as predictors of cheating practice: Modeling and testing. Lentera Pendidikan: Jurnal Ilmu Tarbiyah dan Keguruan, 16(1), 35-52. doi:10.24252/ lp.2013v16n1a3.

Murdiono, M. (2010). The strategy of internalizing religious moral values in the learning process in higher education. Cakrawala Pendidikan, 1(3), 99-111. doi:10.21831/cp.v1i3.239.

Paxton, J. M. \& Greene, J. D. (2010). Moral reasoning: Hints and allegations. Topics in Cognitive Science, 2(3), 511-527. doi:10.1111/j.1756-8765.2010.01096.x.

Prihantini, F. N. \& Indudewi, D. (2016). Plagiarism awareness and behavior among students (Study of the faculty of economics student, majoring in Accounting Semarang University). Jurnal Dinamika Sosial Budaya, 18(1), 68-75. doi:10.26623/jdsb.v18i1.559.

Poless, P. G., Torstveit, L., Lugo, R. G., Andreassen, M., \& Sütterlin, S. (2018). Guilt and proneness to shame: Unethical behaviour in vulnerable and grandiose narcissism. Europe's Journal of Psychology, 14(1), 28-43. doi:10.5964/ ejop.v14i1.1355.

Pringle, J., Drummond, J., McLafferty, E., \& Hendry, C. (2011). Interpretative phenomenological analysis: A discussion and critique. Nurse Researcher, 18(3), 20-24. doi:10.7748/nr2011.04.18.3.20. c8459. 
Reyaan, M. N. \& Hary, T. P. (2017). The relationship between self-confidence and cheating behavior in students. Jurnal Spirits, 6(1), 18-22. doi:10.30738/spirits. v6i1.1068.

Roberts, F., Thomas, C. H., Novicevic, M. M., Ammeter, A., Garner, B., Johnson, P., \& Popoola, I. (2018). Integrated Moral Conviction Theory of student cheating: An empirical test. Journal of Management Education, 42(1), 104-134. doi:10.1177/1052562917710686.

Robertson, M. \& Walter, G. (2007). A critical reflection on utilitarianism as the basis for psychiatric ethics. Journal of Ethics in Mental Health, 2(1), 1-4. http://hdl. handle.net/10822/965360.

Santoso, D. \& Yanti, H. B. (2016). Pengaruh perilaku tidak jujur dan kompetensi moral terhadap kecurangan akademik (academic fraud) mahasiswa akuntansi. [The influence of dishonest behavior and moral competence on academic fraud of accounting students]. Jurnal Akuntansi Trisakti, 3(1), 57-72. doi:10.25105/jat. v3i1.4915.

Schein, C. \& Gray, K. (2018). The theory of dyadic morality: Reinventing moral judgment by redefining harm. Personality and Social Review, 22(1), 32-70. doi:10.1177/1088868317698288.

Silvana, H., Rullyana, G., \& Hadiapurwa, A. (2017). Students' perception on the act of plagiarism in writing final assignment. Jurnal Eductech, 16(3), 338-347. doi:10.17509/e.v16i3.8508.

Shara, S. (2016). Hubungan self-efficacy dan perilaku menyontek (cheating) pada mahasiswa fakultas psikologi Universitas $X$. [Relationship of self-efficacy and cheating behavior at the students of the faculty of psychology, X University]. Jurnal Ilmiah Psikologi Gunadarma, 9(1), 42-49. https://ejournal.gunadarma. ac.id/index.php/psiko/article/view/1542.

Sheng, C. L. (1998). A utilitarian general theory of value (61 $1^{\text {st }}$ ed.; R. Ginsberg, ed.).
Amsterdam: Rodopi BV.

Shweder, R. A., Much, N. C., Mahapatra, M., \& Park, L. (1997). The "Big Three" of morality (autonomy, community, divinity) and the "Big Three" explanations of suffering. In A. M. Brandt \& P. Rozin (Eds.). Morality and Health. London: Routledge, pp. 119-172.

Sitorus, D. S., \& Kristiani, S. (2019). The effectiveness of Accounting e-module integrated with character value to Improve students's learning outcomes and honesty. Cakrawala Pendidikan, 38(1), 120-129. doi:10.21831/cp.v38i1.20878.

Smith, J. A., \& Osborn, M. (2008). Interpretative phenomenological analysis. In J.A. Smith (Ed.). Qualitative Psychology: A practical guide to research methods. London: Sage, pp. 53-80.

Tangney, J. P. (1990). Assessing individual differences in proneness to shame and guilt: Development of the self-conscious affect and attribution inventory. Journal of Personality and Social Psychology, 59(1), 102-111. doi:10.1037/00223514.59.1.102.

Tangney, J. P., Stuewig, J., \& Mashek, D. J. (2007). Moral emotions and moral behavior. Annual Review of Psychology, 58(1), 345-372. doi:10.1146/annurev. psych. 56.091103.070145.

Torstveit, L., Sütterlin, S., \& Lugo, R. G. (2016). Empathy, guilt proneness, and gender: Relative contributions to prosocial behaviour. Europe's Journal of Psychology, 12(2), 260-270. doi:10.5964/ ejop.v12i2.1097.

Tracy, J. L., \& Robins, R. W. (2004). Putting the self into self-conscious emotions: A theoretical model. Psychological Inquiry, 15(2), 103-125. doi:10.1207/ s15327965pli1502_01.

Tracy, J. L. \& Robins, R. W. (2007). The self in self-conscious emotions a cognitive appraisal approach. In J. L. Tracy, R. W. Robins, \& J. P. Tangney (Eds.). The self- 
conscious emotions: Theory and research. New York, NY: The Guilford Publications, pp. 3-20.

Waldmann, M. R., Nagel, J., \& Wiegmann, A. (2012). Moral judgment. In K. J. Holyoak \& R. G. Morrison (Eds.), The Oxford handbook of thinking and reasoning. New York, NY: Oxford University Press, pp. 364-389. doi:10.1093/ oxfordhb/9780199734689.013.0019.

Warsiyah, W. (2015). Cheating behavior of muslim students. Wahana Akademika: Jurnal Studi Islam dan Sosial, 2(2), 31-
50. doi:10.21580/wa.v2i2.376.

Yang, S. C., Chiang, F. K., \& Huang, C. L. (2017). A comparative study of academic dishonesty among university students in Mainland China and Taiwan. Asia Pacific Education Review, 18(3), 385-399. doi:10.1007/s12564-017-9497-2.

Zalnur, M. (2012). Plagiarism among students in making lecture assignments at Tarbiyah Faculty IAIN Imam Bonjol Padang. Jurnal Al-Ta'lim, 1(1), 55-65. doi:10.4049/ jimmunol.1101457. 